\title{
FUSÃO, APAGAMENTO, ASSIMETRIA E REPRESENTAÇÃO EM ARMADILHA PARA LAMARTINE DE CARLOS \& CARLOS SUSSEKIND
}

Fusion, erasure, asymmetry and representation in Armadilha para Lamartine by Carlos \& Carlos Sussekind

\author{
Fabio Bortolazzo Pinto*
}

\section{Introdução}

$A$

rmadilha para Lamartine (1976), de Carlos \& Carlos Sussekind é um dos romances mais desconcertantes e originais já produzidos no Brasil. Seja

pela estrutura, seja pelo tema ou pela forma que o autor encontrou para confundir o leitor, conduzindo-o, delicadamente, a um labirinto referencial praticamente sem saída, tudo colabora para fazer de Armadilha um texto único.

Certas peculiaridades deste livro precisam ser apontadas a fim de, pelo menos, estimular o debate acerca da obra de Carlos Sussekind, autor cuja maestria e inventividade carecem de maior divulgação não só no restrito meio acadêmico.

Atentarei, para fins desta análise, ao mecanismo de "fusão" e "apagamento" do narrador e suas motivações profundas dentro do contexto da obra, e a certas características específicas dos personagens Espártaco e Lamartine, duas vozes narrativas que se tornam u ma terceira, no decorrer da narrativa.

* Universidade Federal do Rio Grande do Sul 


\section{A armadilha}

Eis a armadilha:

Rio de Janeiro, 1954. Uma família de classe média passa por uma sensível mudança em sua rotina. Lamartine M., filho mais moço de D. Emília e do eminente jurista Espártaco M., resolve sair de casa. Quer morar com os amigos em uma "república". Para o pai, trata-se de uma extravagância descabida, para o filho, da única saída possível de uma prisão sutilíssima. Lamartine sente-se aprisionado ao diário do pai, uma prisão "feita de amor", onde o cotidiano da família M. é exposto minuciosamente, como se o registro escrito, e apenas ele, fosse capaz de dar ao mais inexpressivo acontecimento cotidiano o estatuto de realidade.

Mesmo morando com os amigos, Lamartine não consegue se desvencilhar da família, volta e meia retorna à casa dos pais, onde seu antigo quarto permanece intacto. A busca pela autonomia vai lentamente esfacelando sua já vacilante personalidade. No ápice da crise de identidade, Lamartine se despe e vai de encontro ao mar, sendo, logo a seguir, detido pela polícia. É, então, internado em um sanatório.

A narrativa é feita em duas partes. Na primeira, "Duas Mensagens do Pavilhão dos Tranqüilos", temos o relato das aventuras de Lamartine no sanatório, escritas pelo próprio, fazendo-se passar por outro interno, Ricardinho. A Segunda, "Diário da Varandola-Gabinete", é um recorte do diário de Espártaco, reescrito "telepaticamente" por Lamartine em sua estada no sanatório, abrangendo o período que vai de outubro de 1954 a agosto de 1955.

\section{Montando a armadilha}

A primeira coisa que se lê em Armadilha para Lamartine é o seguinte "esclarecimento":

Acham-se aqui reunidos, sob o título geral de "Armadilha para Lamartine":

a) O "Diário da Varandola-Gabinete". O Diário de Dr. Espártaco M., fragmentos referentes ao período de outubro de 1954 agosto de 1955. Começa com o abandono da casa por seu filho Lamartine e termina com o retorno do "pródigo", depois de uma 
permanência de dois meses no Sanatório Três Cruzes do Rio de Janeiro.

b) As "Duas Mensagens do Pavilhão dos Tranqüilos". Escritas por Lamartine M., no Sanatório, fazendo-se passar por um outro doente (Ricardinho). Dr. Espártaco havia travado conhecimento com este último quando as visitas ao filho ainda lhe estavam proibidas; Ricardinho fizera-lhe então algumas revelações (vejase às páginas 234-5 deste volume), merecendo do Dr. Espártaco o título de "informante extra-oficial". Lamartine se entusiasmou com o imprevisto da ligação Espártaco-Ricardinho e imaginou alimentá-la com essas "mensagens", de conteúdo em geral ultrajante para os médicos do Sanatório. Elas chegaram a ser escritas mas ficaram escondidas num lugar que só Lamartine sabia. Foram entregues a Dr. Espártaco (que, como de costume, as incorporou ao Diário) depois da volta à casa e à normalidade. ${ }^{1}$

O caráter aparentemente simples, introdutório, de tal apresentação, subvertese logo na página seguinte a ela, onde o leitor se depara com as "Duas Mensagens do Pavilhão dos Tranqüilos" e não com o "Diário da Varandola-Gabinete", como seria de se esperar visto que as duas partes são, num primeiro momento, apresentadas na ordem inversa. O que poderia passar apenas como algum "gratuito pendor líterosubversivo", no dizer de Hélio Pellegrino, torna-se significativo na medida em que, durante a leitura do "Diário da Varandola-Gabinete", o leitor atento se dá conta de que o que está nas "Duas Mensagens do Pavilhão dos Tranqüilos" é justamente a "verdade não escrita e, portanto, informulada, do 'Diário da Varandola-Gabinete".'. Ora, se o diário de Espártaco, que ocupa, digamos, noventa e nove por cento do livro, ou seja, quantitativamente é o próprio livro, oculta justamente aquilo que o torna relevante para a narrativa, a "verdade informulada", nada mais natural do que figurar após a breve, porém intensa e "honesta", verdade das "Duas Mensagens". No texto de autoria apenas de Lamartine (o que lemos no "Diário da VarandolaGabinete" seria a versão "telepática" de Lamartine do diário do pai) estaria exposta, afinal, a essência do patético drama de Espártaco: no metódico registro dos fatos cotidianos, no monólogo obsessivo, na racionalização exacerbada de tudo que

1 SUSSEKIND, Carlos \& Carlos. Armadilha para Lamartine. 3. ed. São Paulo: Cia. das Letras, 1998.p. 9.

2 PELLEGRINO, Hélio. Armadilha para o leitor. In: Armadilha para Lamartine. 3. ed. São Paulo: Cia das Letras, 1998. p. 300. 
PINTO, F. B. Fusão, apagamento, assimetria e representação em...

acontece à sua volta, consiste sua loucura. Só é possível, porém, chegar a tal conclusão tendo-se em mente a leitura das "Duas Mensagens do Pavilhão dos Tranqüilos".

A partir do discurso de Lamartine nas "Duas Mensagens" é possível entrever o que há por trás do esforço de Espártaco em manter o controle sobre os acontecimentos. Trata-se de uma fuga desesperada de encarar a própria subjetividade. Negando-se a submeter os fatos expostos a uma análise profunda, Espártaco torna seu texto um relato apócrifo da própria existência. Não é por acaso que, voltando Lamartine à "casa e à normalidade", as "Duas Mensagens" sejam "incorporadas" ao diário. O que não é registro, o que não está incorporado à ordem artificial do diário, deixa perigosamente aberta a chaga que poderia, em contato com o caos insuportável da realidade, levar à catarse, ao surto, não apenas o patriarca, mas toda família. Incorporadas as "Duas Mensagens", ou seja, absorvido aquilo que seria a única parte da narrativa escrita declaradamente por Lamartine, está vetada a possibilidade de libertação, de crise, que as "Duas Mensagens" poderiam representar. A família está segura. No fim das contas, tudo volta “à normalidade”. Mas, até quando?

O que temos do diário de Espártaco é o período que vai da saída de Lamartine de casa até seu retorno a ela (outubro de 1954 a agosto de 1955). O que acontece depois disso é mistério. A única pista que temos sobre o que aconteceu é o fato de que as "Duas Mensagens", o registro do ponto-de-vista de Lamartine sobre sua estada no sanatório, foi incorporada ao diário, ou seja, passou a fazer parte da loucura do pai. Já então se vislumbra o jogo de espelhos e a fusão dos narradores que faz com que ambos, simplesmente, desapareçam. Por outro lado, sabendo que as "Duas Mensagens do Pavilhão dos Tranqüilos" foram incorporadas ao diário, como dizer que não fazem parte do próprio diário e que reproduzem não o discurso autêntico de Lamartine ou de Espártaco, mas o do próprio diário que, a estas alturas, diante de tamanha confusão autoral, narra-se a si mesmo?

Acreditando estar acompanhando a montagem da armadilha, o leitor, sem perceber, já não consegue mais sair dela, jogado que está, no dizer de uma leitora ilustre deste livro, Ana Cristina César, "num poço sem fundo de associações". ${ }^{3}$

3 CÉSAR, Ana Cristina. Para conseguir suportar essa tonteira. Opinião, n. 201, 10 set. 1976. p. 53. 


\section{O côncavo e o convexo}

Parece-me interessante, e possível, caracterizar os supostos narradores de Armadilha para Lamartine, a partir de seus discursos, como duas superfícies assimétricas: uma côncava, voltada para dentro, cavada, profunda, e outra convexa, voltada para fora, protuberante, sem profundidade alguma. Da assimetria entre os dois discursos surgiriam espaços, silêncios significativos. Se a incorporação de um texto pelo outro é feita de modo a apagar a autoria dos dois e jogar o leitor num poço sem fundo, o resgate de sentidos só pode se dar através da análise não apenas do que está dito na narrativa, mas do que se silencia. A constatação não é minha nem é nova, foi apresentada em 1976 por Hélio Pellegrino em seu posfácio à Armadilha para Lamartine intitulado "Armadilha para o leitor":

Há no "Diário" um silêncio, uma ocultação, uma meia-palavra que jamais chega à palavra plena, radicalmente reveladora da subjetividade de quem a assume. É desse silêncio e desse vazio, inscritos no centro mesmo do discurso do Dr. Espártaco M., que brota a crise de Lamartine e a descrição que dela faz. ${ }^{4}$

Partindo do levantamento das meias-palavras, dos silêncios de Espártaco, podese caracterizá-lo como um narrador convexo, refratário a qualquer aprofundamento. Tomemos como exemplo um trecho da "avaliação" que faz do ano de 1954:

Não tenho grandes queixas do ano que ora finda. (...) De saúde, vamos indo tão satisfatoriamente quanto possível. Eu vou suportando a minha escherichia. Ela [Emília], a sua menopausa. Nossas pressões sangüíneas não são alarmantes. Os nossos órgãos estão regularmente. O dinheiro poderia ser mais. Mas não está faltando. E há sempre a esperança de que melhore, de uma hora para outra...

Ainda não perdi as esperanças de uma melhoria boa nos meus vencimentos. Vindo, poderemos pensar num repouso maior. Melhoramentos de vida, reformando a Casa, proporcionandonos maior conforto. Confesso-me satisfeito. Comigo. Com os meus. Com o meu trabalho. Com a vida. Já é alguma coisa. ${ }^{5}$

4 PELLEGRINO, op. cit., p. 300.

5 SUSSEKIND, op. cit., p. 90. 
PINTO, F. B. Fusão, apagamento, assimetria e representação em...

Todos os motivos para celebrar 1954 são de ordem racional: os "órgãos estão regularmente", o dinheiro "poderia ser mais, mas não está faltando" e ainda há "esperança" de que a vida melhore. Espártaco se confessa "satisfeito", pois não há nada interno (a não ser a escherichia, uma bactéria intestinal) atrapalhando sua existência. Tudo que poderia ser motivo de preocupação vai muito bem, obrigado.

Com efeito, é sempre a partir de preocupações "palpáveis", "externas" que se estrutura a narrativa convexa de Espártaco. Ao encontrar-se com Lamartine, o pólo côncavo, altamente subjetivo, da narrativa, há sempre uma certa artificialidade e um descompasso significativos:

Lamartine fica para dormir e me pede que converse com ele. Minha conversa com meu filho é sobre os problemas do AlémTúmulo. Para começar, leio-lhe um trecho do livro L'Hôte inconnu de Maeterlinck. Depois, vamos, sozinhos, pelo impulso. Lá pelas tantas, como me sirva de água gelada, sou acometido de uma tremenda crise de soluços. Foi uma luta para passar! Bebi água com açúcar, fiz massagens, tranquei a respiração. Nada! Afinal, quando quis acabar, acabou. ${ }^{6}$

Nesta passagem, quando a conversa avança para além do monólogo mediador (a leitura de Maeterlinck), ocorre um desvio, um "trancamento" literal das possibilidades de discussão (o ataque de soluços). Seria realmente espantoso que um diálogo entre Espártaco e Lamartine, sobretudo com relação aos "problemas de Além-Túmulo", engrenasse. Da mesma forma, faltam palavras a Espártaco quando Lamartine, internado, fala com ele ao telefone:

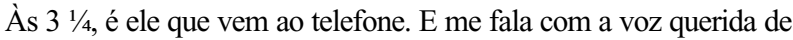
sempre, de que já andava morto de saudade. Fico sem saber o que lhe diga... Por fim, tudo o que sai é um "folgo muito", de que ele deve ter se espantado. Para corrigir a burocracia da expressão, acrescentei apenas “Então, até brevíssimo, não?". Ele ainda se riu.

6 Ibid., p. 65.

7 Ibid., p. 237-238. 
Como já foi dito, nos silêncios de Espártaco, naquilo que não consegue dizer ou demonstrar, reside sua subjetividade, ou a falta dela. Espártaco, porém, não é totalmente indiferente às conseqüências de sua contenção expressiva. Tanto que aponta para a "burocracia" do "folgo muito" e para o espanto de Lamartine diante de sua frieza.

A prova de que o filho, de alguma forma, o compreende é o riso no final do diálogo.

Há apenas dois momentos, no diário, em que Espártaco faz apreciações mais detidas, líricas até, de alguma coisa. Ao ir ao banheiro, descobre que expeliu, junto com as fezes, a já citada escherichia:

O que sentia na barriga revelou-se: fui "lá dentro" e verifiquei, depois, a presença da minha já esquecida escherichia coli. Lá estava, igualzinha, no seu manto envolvente... (...) a escherichia ainda está olhando para mim do seu leito de seda entre as fezes... ${ }^{8}$

A escherichia é apreciada justamente porque será rejeitada. Espártaco não tem controle sobre a bactéria mas pode, no momento que desejar, ver-se definitivamente livre dela. Basta dar a descarga. Trata-se, afinal, de uma surpresa controlável, que não ameaça o cotidiano, o real. Note-se que o lirismo de Espártaco somente reproduz o que vê e sua metáfora não ultrapassa o horizonte do "possível"; mantém-se na superfície. Por outro lado, Espártaco demonstra certo carinho para com as fezes e a bactéria que "gestou". Carinho como o de... uma mãe para com o filho! É curioso perceber como Espártaco consegue demonstrar a algo que foi gerado dentro de si, produto de seu próprio organismo, a afeição que não lhe é possível demonstrar a Lamartine. O filho independe do corpo do pai, não está totalmente sob seu controle, enfim, não é o próprio pai. Diante disso, cria-se para Espártaco uma intransponível barreira emocional e expressiva.

Numa outra passagem, falando sobre os rémedios que toma regularmente, Espártaco faz, sobre eles, uma inesperada apreciação estética:

Meu primeiro cuidado, agora, é tomar os medicamentos na devida ordem. Preparo o copo de água. Tomo, primeiro, o comprimido

8 Ibid., p. 76. 
PINTO, F. B. Fusão, apagamento, assimetria e representação em...

amarelo (que cor linda!) do Irgapirim. Depois, o embaciado, neutro, inexpressivo, do Andrioquim. Finalmente, o chato, feio, de Belexa, desintoxicante pelas várias vitaminas $\mathrm{B}$ que contém (B-1, B-2 e B-6). ${ }^{9}$

Assim como a escherichia é tratada com carinho, os remédios, que mantêm o interior do corpo sob controle, são apreciados, não por acaso, em sua beleza ou feiúra externa. Os remédios estão "a serviço" de Espártaco, por isso, para ele, são esteticameneinteressantes.

Diferente é a posição narrativa de Lamartine, que não se deixa avistar a não ser através dos bilhetes e cartas que Espártaco insere no diário (vale lembrar novamente que as "Duas Mensagens do Pavilhão dos Tranqüilos", o discurso "direto" de Lamartine, foram incorporadas ao diário e são assim, da mesma forma, interpolações). Uma destas interpolações de Lamartine ao diário é uma carta enviada de Maceió a Espártaco:

Arquivo a cartinha do Lamartine (de Maceió, 1/2/1955)

Meu Pai.

Esse bonitão está com a fisionomia cansada de fato [refere-se a uma foto $3 \times 4$ de Espártaco] mas a carta que me mandou sugerindo-me uma fórmula fantástica, infalível para cortar os enjôos - trouxe a sua imagem inalterável: a que eu costumo enquadrar nos passeios que fazíamos pela praia deserta ao amanhecer, os dois exploradores à cata de objetos esquecidos na areia (você falava em alguém da família que tinha encontrado pérolas numa caixinha de fósforos - lembra-se?) ou trazidos pelo mar. Quase vinte anos depois (eu tinha 4 para 5), a temperatura e a luminosidade daquelas manhãs permanecem sendo Você, numa esfera que nada tem a ver com os maus humores e os cansaços cotidianos.

O tom meio nostálgico desta carta é por causa da impressão indizível que deixa na gente o azul, ao mesmo tempo intenso e límpido, do alto-mar (é a mesma intensidade do "azul ultramarino" dos pintores, só que mais transparente). Você vive

9 Ibid., p. 46. 
dizendo que eu não aprecio a Natureza (e não ligo muito mesmo), mas o mar é como se fosse a natureza de um outro mundo.

Um abraço do filho que espera te rever em uma semana.

Lamartine $^{10}$

Lamartine demonstra carinhosamente a onipresença do pai, faz referências à "luminosidade" e ao "azul do mar" que serão retomadas em outra "nota", igualmente inserida no diário, mas sem nenhum tom "nostálgico". As pérolas na caixinha de fósforos dão conta de um horizonte: o horizonte mental da classe a que o pai pertence. Inesperadamente, pode surgir um tesouro, um acontecimento fortuito capaz de mudar o cotidiano. Trata-se de uma visão "lotérica" da vida. Contar com o acaso é uma forma de imobilidade.

No discurso côncavo de Lamartine, imagens reaparecem e são sensivelmente modificadas num contexto pré-crise, pré-internação. Quando Espártaco decide acabar com o diário, pois Emília o acha uma "perda de tempo", Lamartine, às vésperas do "surto", entrega-lhe a "nota" abaixo:

No dia 7 de junho de 1955 às 4 horas da tarde Lamartine o Filho saturado de leituras e sentindo-se cada vez menos capaz de assumir qualquer papel na vida quer no plano das relações afetivas quer no das obrigações profissionais voltou-se para o mar azul que se descortina da janela na varanda da sala e seguindo-o até onde estava acostumado a supor que fossem os seus limites com o céu deixou de perceber tais limites não porque o horizonte se mostrasse enevoado nem porque houvesse ali excesso ou falta de luz mas porque de repente Lamartine o Filho tornara-se para sempre insensível à noção mesma de horizontes Nasceu do seu espanto frente a essa perda queira Deus irreparável de um ponto de referência no mundo a breve exclamação que muitas horas depois trouxe ao conhecimento de Espártaco o Pai solicitando-lhe fosse perpetuada no Diário da

Varandola-Gabinete em testemunho do seu arrebatamento Esta a exclamação

CLARA LUZ QUE SE ACENDE SEM ADEUS NEM CARINHO $^{11}$

10 Ibid., p. 112-113.

11 Ibid., p. 188. 
PINTO, F. B. Fusão, apagamento, assimetria e representação em...

Na carta de Maceió, está clara a associação entre Espártaco, a luminosidade do sol, o azul do mar, a caixinha de fósforos, ou seja, aos "horizontes" que Lamartine reconhece como limites espaciais e, pode-se dizer, existenciais. Se, na carta, estes horizontes têm uma materialidade inegável, na "nota", tornam-se limites subjetivos, metáforas que definem uma relação que se rompe. O filho deixa de perceber os limites associados ao pai (e ao texto: note-se que na "nota" não há pontuação) e conquista, então, "luz própria", torna-se "clara luz que se acende sem adeus nem carinho".

À medida que acompanhamos a busca de Lamartine pela autonomia existencial, cujo ápice é o momento em que se despe, literalmente, e vai caminhando, nu, em direção ao mar, acompanhamos o desenho cada vez mais claro de seu perfil. Não há quase nenhum indício "físico" de sua existência, apenas a presença, cada vez mais eloqüente, de sua subjetividade fragmentada.

A única descrição (quase relatório) que temos do "surto" de Lamartine, é de Espártaco:

Conseguindo sair [Lamartine] sem que eu o visse, foi para a praia (não aqui defronte, mas no Posto 1 , junto à Pedra do Leme) e lá, depois de ficar inteiramente $n u$ - quando foi censurado pelos que estavam na praia (entre 8:00 e 8:30 da manhã) com bolas de areia molhada jogadas à distância - atirou-se n'água. Da água foi retirado pela Radiopatrulha e levado para a Delegacia do Segundo Distrito Policial. Daí é que telefonaram para cá, avisando. (...) Com uma expressão que nunca poderá sair da nossa retina enquanto vivermos, expressão abobalhada, profundamente abatida e triste, com um sorriso estúpido indescritível, só me pareceu ver, à minha frente, um psicopata inteiramente desligado da realidade. [...] Já, então, entre gracejos e entonações sérias, repetindo que "havia morrido", que estava felicíssimo, que isso "não the custara nada" e que "poderia proporcionar o mesmo a todos", passou a seu lado, no sofá da varanda. Tinha a expressão aparvalhada. Tomei-lhe as mãos entre as minhas. Ficou me dizendo: "Papai! Eu não sabia que custava tão pouco morrer! Eu nem senti! E hei de fazer com que todos vocês venham comigo! Eu posso isso porque sou o Cristo!". ${ }^{12}$

12 Ibid., p. 222-223. 
Espártaco não reconhece o filho no "psicopata inteiramente desligado da realidade" que tem diante dos olhos. O sentido das palavras de Lamartine, naturalmente, escapa-lhe. Ficam-lhe apenas os indícios externos da crise: a expressão "abobalhada" e o "sorriso estúpido indescritível" do filho.

Se o narrador côncavo só existe por intermédio do convexo, a recíproca também é verdadeira. Concluir que o que se lê na segunda parte do livro não é o diário de Espártaco propriamente dito mas sua versão "telepática" é abstrair o óbvio. Daí que côncavo e convexo fundem-se num mesmo texto, mas de forma assimétrica, ambos buscando e fugindo do confronto de suas supostas verdades. A tensão entre eles, por nunca se resolver, tende à destruição das bases em que se fundam: a racionalidade e a subjetividade, e aoapagamento de qualquer demarcação segura referente ao(s) narrador(es).

\section{Sanatório}

Depois da "crise", Lamartine é internado no Sanatório Três Cruzes.

Para Espártaco, o sanatório é como "um mero estágio", necessário para que o filho possa ser reintegrado à vida em sociedade. Lamartine tem que ser afastado do convívio familiar e passar por uma etapa de reeducação, através da qual voltará "à razão", esta virtude tão cara ao universo mental do autor do diário. É preciso que a personalidade do filho seja modificada a qualquer custo. A violência dos eletrochoques (essência do tratamento) é apenas uma necessidade "terapêutica". No fim das contas, apesar de dispendioso, o tratamento deverá trazer o resultado que se espera.

Não gosto, entretanto, de saber que ele [Lamartine] ainda não iniciou os choques, porque os médicos temem que lhe tirem a memória, modificando-lhe muito a personalidade. Deve haver um equívoco nisso. A personalidade tem que ser modificada. $\mathrm{O}$ tratamento o exige. Tudo está em saber controlar as modificações, orientando-as. Não gosto, também, de que ele não esteja contente com o Sanatório e desejando voltar quanto antes. Pode ser mais natural isso do que a conformidade em que se achava. Mas receio que the venha, agora, o desejo de fugir, facilitado pela confiança que já ganhou no meio, através dos médicos e das enfermeiras. (...) Uma notícia assustadora: o "tratamento", que ele, Philips, 
PINTO, F. B. Fusão, apagamento, assimetria e representação em...

não cobraria, terá de ser cobrado, porque agora não é mais dos médicos, é da Casa de Saúde. Assim, além das “diárias", tenho de pagar, à parte, quatro contos! Que hei de fazer? Gemerei amanhã com os 7000,00, se não for mais. (...) É despesa sagrada, não se discute. Se for útil a meu filho, não poderia ter melhor emprego. ${ }^{13}$

O "sacrifício" financeiro preocupa Espártaco bem mais do que uma eventual seqüela que os eletrochoques possam causar a Lamartine. A grave ênfase dada ao problema dos custos ("é despesa sagrada") contrasta com a serenidade com que Espártaco fala do "tratamento": em sua convexa concepção, Lamartine deve ser submetido a tudo que o Dr. Philips julgar necessário.

Nas “Duas Mensagens do Pavilhão dos Tranqüilos", Lamartine conta, via Ricardinho, a estréia do "Diário da Varandola-Gabinete", escrito por ele através de "telepatia" e publicado no número 7 do jornalzinho feito por internos do Sanatório, $O$ Ataque. O diário é um sucesso entre os internos, que passam a exigir que seja publicado regularmente.

Nesse número 7 começou a série do "Diário da Varandola" e foi aquele tremendo sucesso. Aliás, uma confirmação do sucesso que já tinha sido a narrativa oral, quando Lamartine (abusando um pouco da nossa credulidade de doentes mentais) fazia de conta que estava lendo no Diário do pai por telepatia. (...) É que o "Diário" falava de coisas presentes, os comentários do pseudo Dr. Espártaco voltavam-se para as experiências do dia-a-dia (...) era uma maneira de mostrar que o Sanatório Três Cruzes não estava desligado da vida e que era possível senti-la e partilhar dela... ${ }^{14}$

A razão do sucesso do diário de Espártaco entre os internos do sanatório está diretamente ligada à maneira como estes concebem a instituição em que se encontram: eles vêem no diário não só o prolongamento do mundo externo, que penetra através de um jornal, mas uma via de mão dupla: sentem-se representados,

13 Ibid., p. 238-251.

14 Ibid., p. 13. 
no diário, para além dosmuros. Note-se que Lamartine não se considera um doente mental. Os internos, aparentemente, também não o consideram louco. Pelo contrário, desconfiam que Lamartine esteja abusando um pouco de sua credulidade de doentes mentais. Diferente é a acolhida de Espártaco, cuja loucura, assim que o diário começa a ser publicado em O Ataque, é pronta e "fraternalmente" reconhecida.

Quanto a mim [Ricardinho], ainda não estava convencido de
que o poeta dos "Senhor! Senhor!" [Lamartine] pudesse ser um
colaborador afinado com a orientação que imprimíamos ao jornal;
até que começou a escrever o "Diário da Varandola", uma série
de imitações do Diário de seu próprio pai, o Dr. Espártaco M.,
personagem que não tardamos a acolher entre nós, em espírito,
presenteando-o com o cocar de nosso carinho e da nossa
fraternidade. ${ }^{15}$

Lamartine corporifica o pai através do diário, trazendo-o para dentro do sanatório. Subvertem-se então as expectativas externas: ao invés de ser integrado ao espaço em que se encontra, Lamartine é que "interna" Espártaco. No sanatório, o diário e seu autor "original" parecem estar "no seu elemento".

Ciente, através de Ricardinho, que Lamartine redige páginas de seu diário "por telepatia" em O Ataque, Espártaco, como é de seu feitio, registra, com certo orgulho e nenhuma profundidade, a iniciativa do filho:

Virou inclusive uma espécie de praxe, depois do jantar, Lamartine contar-lhes como é o Diário. O número de volumes já escritos, o número de prateleiras que ocupam nas estantes, quantas vezes por dia eu me sento para escrever, as dimensões da varandolagabinete $(1,15 \mathrm{X} 1,60 \mathrm{~m}$, segundo ele; dei-me o trabalho de conferir e era isso mesmo!) (...) No início, também, meu filho fazia de conta que estava captando por telepatia certas coisas que "naquele momento mesmo" eu estava escrevendo sobre ele, sobre o Sanatório e inclusive sobre eles próprios (...) mas a idéia de estar invadindo assim minha intimidade foi deixando o pessoal com remorsos, até que um dia Lamartine teve que dizer que era tudo 
PINTO, F. B. Fusão, apagamento, assimetria e representação em...

invenção sua - e aí, um deles, cognominado "Jornalista", pediu a Lamartine que passasse a colaborar no seu jornal, $O$ Ataque, escrevendo todos os dias uma página "inventada" do meu Diário. ${ }^{16}$

Espártaco não parece ver nada demais no fato de Lamartine ser uma espécie de "interlocutor" entre o diário e os internos. Não lhe causa estranhamento que o filho "finja" receber o diário por telepatia nem que saiba de cor as dimensões da varandola. Para ele, não há conexão entre a fixação do filho no diário e a "crise" que lhe motiva a internação.

Nas visões de pai e filho acerca do sanatório, temos, novamente, uma assimetria. Os dois pólos da narrativa, côncavo e convexo, no entanto, quase chegam a trocar de lugar. Numa passagem do diário, Espártaco, descrevendo uma visita ao sanatório em que Lamartine lhe entrega o manuscrito de um romance, desconfia da própria objetividade e censura-se significativamente:

Estou quase - eu também - escrevendo um romance, mas não é minha culpa se os acontecimentos desta manhã foram romanescos; sou o primeiro a não ver com bons olhos a onda de mistérios e aberrantes fantasias que, de há tempos, vem mudando o tom sereno e ponderado que em outras épocas fazia a maior glória deste Diário; há que se levar em conta a heróica resistência que tenho oposto aos ataques que partem de todos os lados, e que culminaram nessa crise espetacular do Lamartine. Ninguém é de ferro. E, se a objetividade sistemática é de se desejar, como um paradigma, também o estar longe de alcançá-lo não deve envergonhar ninguém. (...) quando meu filho voltou do quarto (...) e me entregou a produção literária para eu ler em casa, achei de ficar rondando o grupinho [de internos] por mais alguns minutos (...) Não sei quanto tempo eu ainda teria ficado lá, se não houvesse visto o Philips [Dr. Philips, médico responsável pelo tratamento de Lamartine] entrar na Tesouraria; quando cheguei, porém, à Tesouraria, não era o Philips, era um outro que nunca me cumprimenta e que está sempre a limpar os óculos, e que, dessa vez, ao recolocá-los na cara, pôs-se a olhar-me como se tivesse à sua frente um...*

16 Ibid., p. 233-234. 
Aqui, Dr. Espártaco havia escrito "como se tivesse à sua frente um dos doidos", depois riscou "um dos doidos" e escreveu "um doido", depois riscou "um doido" e deixou assim mesmo, faltando. ${ }^{17}$

\begin{abstract}
A única rasura no texto de Espártaco se dá quando ele é confundido com um louco.

A possibilidade o assusta tanto que é preciso tirá-la do diário, deixando em seu lugar talvez o silêncio mais significativo de toda sua narrativa.

No sanatório, Lamartine se apaixona por Inês, uma interna de outra ala, o "Pavilhão dos Tranqüilos" e só então decide se submeter ao tratamento de "recuperação".
\end{abstract}

Não é nada de muito complicado, essa primeira etapa. É o que, na terminologia da casa, se conhece como "demolição". O eletrochoque ajudando, o próprio paciente faz o resto. Permitese, alimenta-se, incentiva-se toda sorte de inclinações mórbidas. Que a doença se agrave - tanto melhor! É o que se quer. Há de chegar a um ponto, a um extremo - e os médicos seguem o processo com a maior das indiferenças, espaçando ou concentrando as descargas elétricas - em que ocorra o colapso total. O doente se destrói e está em condições de ser reconstruído por Philips e Cia. no doce ambiente do Pavilhão dos Tranqüilos. ${ }^{18}$

Se na "terapêutica" do sanatório é necessário que o paciente atinja o ápice da crise, o "colapso total" para poder ser "reconstruído", ou seja, remodelado de acordo com as expectativas sociais externas, para Lamartine, que não se acredita doente ou interdito, resta "bolar um plano" para enganar os médicos, forjar uma crise aguda para ser submetido ao tratamento e chegar ao pavilhão dos tranqüilos. Em dado momento, durante a execução do plano, Lamartine não precisa mais forjar 
PINTO, F. B. Fusão, apagamento, assimetria e representação em...

o "colapso", fica "um trapo", sendo levado para a cama pelos companheiros (não pelos enfermeiros, nem pelos médicos). No meio da noite, passa por uma estranha experiência: uma enfermeira, acompanhada pelo Dr. Philips, aplica-lhe uma espécie de eletrochoque usando a própria língua como indutor. Depois disso, pela manhã, Lamartine pede cigarro a um dos companheiros de quarto e queima o próprio pulso, mostrando ao enfermeiro e dizendo que outro interno lhe havia queimado. Só então decidem transferi-lo para um quarto no pavilhão dos tranqüilos, não tanto pela "encenação" da crise quanto pelo fato de que entre internos aquilo (de um queimar o outro com cigarro) nunca tinha acontecido.

No mesmo dia, às 11 horas, hora do almoço, Lamartine foi transferido para um quarto particular no Pavilhão dos Tranqüilos - vitória que comemorou chupando meia dúzia de limas, como já tive ocasião de contar; que lhe permitiu desfrutar da companhia de Inês muito mais do que antes; e que só teve a ensombrecê-la a notícia, que the deram depois, de que os choques continuariam. ${ }^{19}$

Com a melancólica nota de que "os choques continuariam" termina a narrativa de Lamartine/Ricardinho nas "Duas Mensagens do Pavilhão dos Tranqüilos". De um ponto de vista diacrônico, os acontecimentos descritos até aí, têm sequência no "Diário da Varandola-Gabinete". Lamartine passa pelo tratamento e volta para casa, não exatamente "reconstruído". Não fica claro, aliás, se há alguma mudança significativa no comportamento de Lamartine. Espártaco registra-lhe apenas o aspecto, nunca sua real disposição de espírito.

O diário também continua a ser escrito, a julgar pelo penúltimo parágrafo do livro:

E aqui encerro este caderno, $\mathrm{o} 67^{\circ} \mathrm{com}$ que já conta o meu diário. O $68^{\circ}$ está comprado, iniciá-lo-ei amanhã. Foram três meses inteiros, e, neles, quanta dor, quanto sofrimento com a internação de Lamartine! ${ }^{20}$

19 Ibid., p. 29.

20 Ibid., p. 295. 
O "Diário da Varandola-Gabinete" e as "Duas Mensagens do Pavilhão dos Tranqüilos" terminam, sincronicamente, num vislumbre de continuidade. Os choques continuarão, assim como o diário. Que sentido há em tal coincidência? Como tudo em Armadilha para Lamartine, isto também não é acidental. Os choques e o diário são o tormento de Lamartine. A conclusão a que se chega é que, ao menos neste livro, seu sofrimento não acabará.

\section{A armadilha como representação}

Ampliando o espectro de leitura, se tomarmos a família M.e, particularmente, seu chefe, Espártaco, como representativos de uma classe social inserida num contexto histórico específico, temos nada menos que a denúncia da fragilidade de uma estrutura política, econômica e social prestes a convulsionar-se.

Se a leitura da obra por este ângulo pode, hipoteticamente, ser vista como arbitrária, ao menos tem um bom antecedente: Arnaldo Jabor, em artigo de 1991 a respeito da reedição de Armadilha para Lamartine pela editora Brasiliense, conecta a experiência ficcional de Lamartine ao episódio real da internação de Carlos Sussekind, o filho, em um sanatório, aludindo justamente à representatividade do livro enquanto denúncia de uma sufocante e decrépita estrutura social:

No Rio ficou intacto em algumas famílias este museu da burocracia da capital federal, suas vidas bisonhas e tímidas, seu acanhado minueto de parentes, suas luzes mortiças, suas esposas tristes, seus filhos reprimidos, sua tola contemplação da vida nacional.

Lá está a memória das pequenas alegrias, os aniversários, os casamentos infelizes, o funcionalismo público e o funcionalismo da casa. Entender o horizonte mental desta época talvez dê algumas chaves para decifrar a pequenez de nosso desastre político. Carlos Sussekind rasga este segredo, trai a sua classe e lança luz sobre este mundo reprimido que o pariu. Ele denunciou uma vez este mundo de sombras por uma crise de loucura, e depois pela literatura. $^{21}$

21 JABOR, Arnaldo. Pai e filho dão chave para labirinto brasileiro. Folha de São Paulo, 30 nov. 1991.p. 6. 
PINTO, F. B. Fusão, apagamento, assimetria e representação em...

No diário de Espártaco, estamos realmente diante da "tola contemplação da vida nacional" característica da classe média brasileira ilustrada e "remediada" da década de 50, da qual o autor é representante exemplar. A compreensão da "pequenez de nosso desastre político" seria, efetivamente, a chave de leitura que nos permitiria enxergar Armadilha para Lamartine como um "romance-denúncia", uma exposição detalhada da situação imediatamente anterior à crise política (leia-se desenvolvimentismo, mudança e conseqüente isolamento da sede do governo federal em Brasília, golpe militar, ditadura) gestada durante o período registrado no diário, 1954-55. Em 1955, a corrida política pela sucessão de Café Filho divide as duas grandes forças políticas de então: a UDN, com a qual estavam os militares, e a coligação PSD/PTB, os herdeiros do "getulismo". A eleição de Juscelino Kubitscheck e João Goulart apenas adiou por alguns anos o golpe militar:

Conhecidos os resultados da eleição, podia-se ler em vários órgãos de imprensa que o eleitorado de Juscelino era "formado pela massa ignorante, sofredora, desiludida, trabalhada pela mais sórdida das demagogias e envenenada pela propaganda solerte do Partido Comunista”. Esta foi uma das primeiras manifestações da longa série de manipulações que os conservadores direitistas moveram contra a posse de Kubitscheck e Goulart. (...) Todos os grupos conservadores e anticomunistas das Forças Armadas entraram em prontidão, procurando mobilizar os meios militares para a deflagração de um golpe contra a democracia. ${ }^{22}$

Já havia, no ar, a probabilidade de um golpe de estado, que só se efetivaria realmente em 1964. Espártaco, simpatizante comunista, não deixa de opinar, mantendo-se, no entanto, apenas no senso comum:

Não estou gostando nada dos arreganhos façanhudos dos militares, que estão agora com o freio nos dentes e provocam, despudoradamente a luta com os "paisanos", como se nós, coitados, os estivéssemos prejudicando no que quer que seja; 
nós, contra quem se voltam todas as rodas do carro oficial, esmagados, humilhados e oprimidos até as últimas resistências. ${ }^{23}$

Através dos comentários de Espártaco, da estéril exposição dos acontecimentos políticos que o cercam, temos um panorama histórico passível de ser um dos mais instigantes depoimentos da literatura brasileira acerca deste período:

\begin{abstract}
Por falar em dinheiro, fui, ontem, informado de que, para assegurar o êxito do nosso aumento na Justiça, foi preciso transigir com os militares - hoje e sempre, donos únicos do País. $\mathrm{O}$ vencimento dos generais passará a ser equiparado ao de Ministro do Supremo, descendo a hierarquia pelo Tribunal de Recursos, pelo de Apelação, pelos Juízes de Direito, etc. Estes, e portanto nós, os Curadores, deveremos corresponder a major... um belo fim de vida, sem dúvida! (...) De qualquer forma embora isso represente o descalabro financeiro do País - é a única maneira de fazer o orçamento doméstico folgar um pouco. Porque, agora, até em atrasados já se volta a falar... Mirífico poder da farda! Meu pobre Pai, teria sido essa a República dos teus sonhos? ${ }^{24}$
\end{abstract}

A indignação de Espártaco tem muito mais a ver com individualismo do que com qualquer outra coisa: "de qualquer forma-embora isso represente o descalabro financeiro do País - é a única maneira de fazer o orçamento doméstico folgar um pouco". Os ideais, "os sonhos" são passados de pai para filho sem que, em nome deles, seja necessária qualquer atitude concreta.

A afirmação de Roberto Schwarz de que "a volubilidade de Brás Cubas é um mecanismo narrativo em que está implicada uma problemática nacional", ${ }^{25}$ é perfeitamente aplicável com relação ao mecanismo narrativo de Armadilha para Lamartine. A obsessão burocrática pela rotina, a necessidade de ordenar racionalmente a casa e a família dentro de um sistema "funcional", enfim, a

23 SUSSEKIND, op. cit., p. 70.

24 Ibid., p. 60.

25 SCHWARZ, Roberto. Um mestre na periferia do capitalismo. São Paulo: Duas Cidades; Ed. 34, 2000. p. 47. 
PINTO, F. B. Fusão, apagamento, assimetria e representação em...

contemplação melancólica e tímida de Espártaco M. diante dos acontecimentos sociais, políticos e econômicos, são formas riquíssimas de representação de uma "problemática nacional". Espártaco acompanha a candidatura de Kubistchek à presidência, a briga entre os herdeiros do getulismo e os "lacerdistas" de plantão, conhece pessoalmente alguns dos grandes personagens do jogo político da época, chega a exaltar-se, criticando violentamente (no diário, é claro) líderes militares e religiosos, escandaliza-se com a desorganização econômica do país. Mas, preso de forma exemplar à sua classe, pouco ou nada faz além de olhar, anotar, assistir os acontecimentos. A impotência diante dos fatos é parcialmente suprimida pelo controle da casa. Controle este, que só é total nas páginas de seu diário. É nestas páginas que aprisiona, como borboletas, os membros da família, e é justamente contra elas (decodificando-as, incorporando-as, deformando-as) que arremete Lamartine. A atitude de libertação não se restringe apenas ao diário, atinge um âmbito maior. Lamartine trai sua classe, desnuda toda a pobreza existencial de um modo de vida progressista na aparência, arcaico e opressivo em essência.

O apagamento da autoria está diretamente relacionado a esta "traição de classe". Sendo Espártaco, assim como Carlos Sussekind Mendonça (o pai de Carlos Sussekind), representante de uma classe média acomodada (e aqui entramos no pantanoso terreno extra-ficcional), cuja alienação termina por entregar o país aos militares, o fato de Carlos Sussekind, o filho, como Lamartine, reescrever os diários do pai, apagando-lhe a autoria é uma forma de denunciar a inutilidade de uma classe social amorfa, passível de ser "apagada" da história sem maiores conseqüências. Ou melhor, com conseqüências até benéficas ao país.

\section{RESUMO}

Estudo de certas estratégias narrativas utilizadas por Carlos Sussekind em Armadilha para Lamartine. Entre elas, o apagamento da figura do narrador através da fusão de duas vozes narrativas discursivamente assimétricas. Com isso, busca-se encontrar a lógica estrutural do romance e seu significado ideológico, político e social.

Palavras-chave: Narração, romance, representação. 


\title{
RESUMEN
}

Estudio de ciertas estrategias narrativas utilizadas por Carlos Sussekind en Armadilha para Lamartine. Entre ellas, el apagamiento de la figura del narrador através de la fusión de dos voces narrativas discursivas. Con eso, busca-se encontrar la lógica estructural del romance y su significación ideologica, politica y social.

Palabras-clave: Narración, romance, representación.

\begin{abstract}
A study of certain strategies used by Carlos Sussekind in Armadilha para Lamartine. Among these there is the erasure of the narrator through the fusion of two narrative voices discursively asymmetric. Due to this, an attempt is made to uncover the structural rationale of the novel and its ideological, political, and social significance.

Key-words: Narration, novel, representation.
\end{abstract}

\section{REFERÊNCIAS}

BARROS, Edgard Luiz de. O Brasil de 1945 a 1964. 6. ed. São Paulo: Contexto, 1999.

JABOR, Arnaldo. Pai e filho dão chave para labirinto brasileiro. Folha de São Paulo, 30 nov. 1991.

PELLEGRINO, Hélio. Armadilha para o leitor. In:Armadilha para Lamartine. 3. ed. São Paulo: Companhia das Letras, 1998.

SCHWARZ, Roberto. Um mestre na periferia do capitalismo. 4. ed. São Paulo: Livraria Duas Cidades; Ed. 34, 2000.

SUSSEKIND, Carlos \& Carlos. Armadilha para Lamartine. 3. ed. São Paulo: Companhia das Letras, 1998. 